DIACRONIE

\section{Diacronie}

Studi di Storia Contemporanea

$\mathrm{N}^{\circ} 13,1 \mid 2013$

Contrabbandieri, pirati e frontiere: per una storia delle pratiche informali nell'America Centrale (XVII-XXI

secolo)

\title{
Interview with Marcus Rediker
}

\section{Bill O'Driscoll}

\section{(2) OpenEdition \\ Journals}

\section{Electronic version}

URL: http://journals.openedition.org/diacronie/703

DOI: $10.4000 /$ diacronie.703

ISSN: 2038-0925

Publisher

Association culturelle Diacronie

Electronic reference

Bill O'Driscoll, «Interview with Marcus Rediker », Diacronie [Online], № 13, 1 | 2013, document 5, Online since 01 April 2013, connection on 19 April 2019. URL : http://journals.openedition.org/diacronie/703 ; DOI : 10.4000/diacronie.703 


\section{Diacronie}

N. 13 | 1|2013 Contrabbandieri, pirati e frontiere

\section{$5 /$}

\section{Interview with Marcus Rediker}

by Bill O’DRISCOLL *

The following is an expanded version of an interview with Marcus Rediker, a shortened version of which was first published in Pittsburgh City Paper. This new version also includes additional material supplied by Marcus Rediker.

\section{Bill O'Driscoll: What interested you in the Amistad case?}

Marcus Rediker: My interest grew out of a book I wrote entitled The Slave Ship: A Human History ${ }^{1}$. In years of research on that book I learned that it was extremely difficult to organize a successful slave revolt on any sort of slaving vessel. The ships themselves were designed to prevent it.

I wanted to figure out how the Amistad Africans did it. How, on a vessel gruesomely known for torture and terror, did this successful rebellion happen? I found that the key to understanding their victory was their African experience: who they were as Africans, what kind of knowledge they had, what kind of skills they had, how they thought about themselves, how they organized themselves. Apart from Sierra Leonean scholars Arthur Abraham and Iyunolu Folayan Osagie, very few who had written about the Amistad rebellion had taken interest in that part of the story. In my view, it is the key to everything.

\section{B. O'D.: Example?}

M. R.: One of the key questions was, how did these Amistad Africans organize themselves in the uprising? No one had studied the question. Many people think that

\footnotetext{
${ }^{1}$ REDIKER, Marcus, The Slave Ship: A Human History, New York, Viking, 2007.
} 
revolts on slave ships were just spontaneous expressions of outrage. Some were, but they were almost never successful.

Organized shipboard revolts required serious planning. I went back to southern Sierra Leone, where the Amistad Africans had came from, to search for their experiences and cultural forms of self-organization. The more I read about this region, the more I came to see the significance of the Poro Society, an all-male secret society that played a central role in community governance.

This issue is complicated because the Amistad Africans consisted of at least 10 different ethnic/national groups. All of these groups, I found, had Poro Societies, as indeed did most all culture groups in southern Sierra Leone. This was an experience shared by all of the men on the ship ( 49 of the 53 on board were men).

The more I read about the Poro Society, the more I saw resonances between its functions and what the men on the ship did, thousands of miles from home. One example of this was that the Poro Society declared war; it had a military function. Did the Amistad Africans think of what they were doing on that ship as an act of war?

I found an extraordinary source, oral history of the rebellion kept by the Amistad Africans and written down by a missionary thirteen years later. In it they preserved memory of the discussion that went on in the hold of the ship as they planned the rebellion. There was a debate, and one of the Amistad Africans, probably Cinque the leader, asked the group, "Who is for war?".

This was a war council, of the Poro Society, meeting in the dark hold of the slaving vessel. All of these men were trained warriors, because warfare had been common in their homelands. This is how they understood what they were doing: they would wage war on the Amistad.

\section{B. O'D.: You also write about the Africans' sense of collective, as opposed to individual, identity.}

If you study life among the Mende - and the Mende made up about two-thirds of the Africans aboard the Amistad - this group has a deeply collective sensibility. They did have some social stratification, wealthier people and poorer people, but they also had a strong corporate sense of the social whole.

How did the group create discipline on the ship and in New Haven jail, where they spent many months? They had their own ideas of leadership and communal social life. Leaders like Cinqué the warrior and Grabeau the high-ranking member of the Poro maintained social discipline and represented the group according to their own 
objectives throughout the ordeal. The entire group was clear from the beginning of the ordeal to the end what they wanted: to go home. "We want to go back to the land of our fathers", they said, invoking the patriarchal side of Mende culture.

After they'd been in jail for a about sixteen months, they actually named their new collective. They began to call themselves "the Mende people". This is a fascinating innovation. They weren't all Mende. But after listening in jail to talk about the powerful and sovereign "American people", they said "We are the Mende people. You are one kind of people, we are another. We are equals. We demand that you respect us as the Mende people". They came to think about themselves in new ways, and they used this collective identity as the Mende people to make their claims to go home.

\section{B. O'D.: The Slave Ship too is about the making of new cultures of circumstance.}

M. R.: The theme comes straight out of The Slave Ship and runs through The Amistad Rebellion from start to finish. On the lower deck of slave ships new kinds of culture were formed: new languages, new songs, new ways of association, new kinds of identification, new friends, new kin, new enemies. Out of that came a new collective in the broadest sense, a kind of African-American culture.

The Amistad rebellion illustrates the process as a group of people moved from a slave-trading fortress in Africa onto a big slave ship on the Atlantic, into the slave pens of Havana, Cuba, onto the Amistad in the Caribbean, and into New Haven jail in North America. You can see what historians sometimes call "ethnogenesis", cultural formation, taking place. It is a conscious process, and the Amistad Africans used it to their advantage.

\section{B. O'D.: What about the African's relationship with the American abolitionists?}

M. R.: It is cooperative but full of tension. This is not surprising because neither group knew anything about the other at the beginning of the encounter. They had to interact, feel their way, build trust. If the kind of history I write is often called "history from below", from the bottom up, here was a case of history made in jail: history from the inside out. Important historical processes were going on in that jail.

Most historians do not consider rebel slaves to be part of the abolitionist movement. They are not usually called abolitionists, even though they resisted slavery, 
sometimes to the point of death. I always thought that slave rebels and abolitionists must to be considered part of a common movement against bondage. A compelling thing about the Amistad case is that right there in jail, African insurrectionists and mostly white American abolitionists met and cooperated toward common ends of winning the case and fighting slavery more broadly. That's a political negotiation and a cultural process, both worthy of close study.

The evidence of the jail experience is massive because thousands of people from all walks of life visited the Amistad Africans behind bars and talked with them through interpreters (African sailors). Many of the visitors wrote down what they saw and thought, some in private letters, others in newspaper articles. As a result the documentation of the Amistad Africans is greater than that of any other group of slave rebels I know.

\section{B. O'D.: Had other writers used that material before?}

M. R.: Some historians had used it, although in minimal ways. The experience of the revolt and the jail had been minimized because scholars concentrated on the courtroom drama to the near exclusion of equally important and dramatic settings.

If one begins the story in Africa and conceives the drama as the struggle against slavery in the broadest, transatlantic sense, the moment of enslavement, the slave ship, and the jail all become important. You don't take the abolitionist view as the only version of the story. You don't see this as a case of white people rescuing poor benighted black people. You see a common struggle. That is what was happening in jail - people black and white were cooperating and building something new, an interracial anti-slavery movement of great power.

\section{B. O'D.: Yet the abolitionists often characterized the Africans as victims.}

M. R.: "Hapless victims", they called the Amistad Africans. These people had made a successful shipboard rebellion and sailed the captured vessel 1.400 miles. They do not appear to have been hapless to me!

To call the Africans hapless reflected the abolitionist self-conception, that good Christians would save and bring the poor pagans to enlightenment. This was how most abolitionists thought about the case, but we can't mistake that for what actually happened. 


\section{B. O'D.The abolitionists were also trying to create public sympathy for the} Africans.

M. R.: Yes, they thought the best way to do this was to turn militant slave rebels into peaceable, docile Christians. They want to maximize public sympathy for them. But one of the really unexpected discoveries of this project was that the popular press, especially the penny press paper the New York Sun, took an interest in the actual rebellion, and depicted the rebels as heroes.

This was unprecedented. Nat Turner's rebellion happened eight years earlier, in 1831, and he was represented in the press as the devil incarnate. I found no heroic depictions of Nat Turner in the white press. But somehow this Amistad rebellion triggered a set of images and writings in which Cinque and the other Africans were pictured in a much more positive light.

Those depictions, which included Cinqué heroically posing with the cane knife he used to kill the captain of the vessel, made abolitionists nervous. Like many others, they feared slave revolt. They thought the public would get the wrong idea. But as it happened the American people were interested in that part of the story. So one of the deep tensions of the case was this: who will represent the Amistad rebels and how, using what kinds of images?

I was also surprised to see just how great the popular interest in the Amistad case actually was, even in places where one would not expect to find it: in penny papers sold to urban laborers and in playhouses for working-class audiences. There's no doubt in my mind the editor of the New York Sun and the proprietor of the Bowery Theater printed and staged the heroic stories and images because they thought they would sell newspapers and theater tickets.

\section{B. O'D.: What accounts for the different reactions to Turner and the Amistad Africans?}

M. R.: The Amistad Africans were not African-American slaves. Nat Turner directly challenged American slavery, while the rebels of the Amistad challenged Cuban slavery. That's a big difference. Relatedly, the slave-owning villains in the story were also Cuban, not American, not the likes of John C. Calhoun and others highly placed in the United States government. This made it easier to laud the slave rebels and vilify their "owners". Still, it was not an easy set of distinctions to maintain: it was dangerous to glorify slave revolt in one of the world's leading slave societies. 


\section{B. O'D.: Is "history from below" such as you practice still unusual?}

M. R.: It was unusual to take this approach to the Amistad case, but we have many good histories from below about the American experience. Social history of many kinds arose from the movements of the '6os and '70s - the civil-rights movement, anti-war movement, student movement, etc. I try not only to include the poor people who have been left out of traditional, "top-down" histories, but to emphasize their history-making power. I try to stress how people's freedom struggles had a dramatic impact beyond their own individual cases.

The Amistad struggle, for example, affected the abolitionist movement, relations between the United States and Spain, the repatriation of people back to Africa - all big, transatlantic effects. I wish to so show the consequences of resistance from below, to demonstrate that these things mattered in to the unfolding of history.

\section{B. O'D.: Is doing history from below different than doing conventional history?}

M. R.: It's harder to do because you have to discover new sources because your subjects did not usually create documents of their own. But in this case there were so many sources that illuminated the lives of the people under study. It was possible to get to know them as individuals - what they thought, how they acted, how cultural precepts informed their thought and action. That kind of evidence makes it possible to understand why things happened as they did.

\section{B. O'D.: Any particular sources you want to mention that you employed?}

M. R.: I found a number of letters by the teacher of the Amistad Africans, a young Yale undergraduate named Samuel Booth, written in the period when they were preparing to go home. In planning repatriation, it became important for abolitionists to draw on African knowledge of their homelands. Booth spent many hours a day with the Africans, teaching them English and conversing with them about who they were and where they had lived. His letters convey much information about their background: several of them had been weavers and many had lived in big cities. These letters had been written by a person who knew them better than anyone else. 


\section{B. O'D.: Where did you find that?}

M. R.: Booth published several letters in a Philadelphia anti-slavery newspaper called the Pennsylvania Freeman. Other letters are preserved in the American Missionary Association archive, in the Amistad Research Center in New Orleans².

\section{B. O'D.: What about that oral history you mentioned, the one that established how the Africans regarded the revolt as war?}

M. R.: That's also in the American Missionary Association archive. The letter, dated October 1852, was written by a woman missionary, Hannah More, who had recently arrived at the Mende Mission, as it was called. An abolitionist friend of hers had requested an account of the Amistad Africans, which she was happy to provide after talking with the four or five who remained at the mission. This letter recounts the Africans' own collective memory of the entire ordeal. It contained precious information to be found in no other historical document.

\footnotetext{
${ }^{2}$ URL: < http://www.amistadresearchcenter.org/archon/?p=collections/controlcard\&id=19 > [accessed 25 april 2013].
} 


\section{* The interviewer}

Bill O'Driscoll is Arts \& Entertainment Editor of Pittsburgh City Paper, a weekly newspaper for which he writes about books, theater, film and visual art, as well as about environmental issues. URL: < http://www.studistorici.com/progett/autori/\#ODriscoll >

\section{Per citare questo articolo:}

O'DRISCOLL, Bill, «Interview with Marcus Rediker», Diacronie. Studi di Storia Contemporanea: Contrabbandieri, pirati e frontiere: per una storia delle pratiche informali nell'America Centrale (XVII-XXI secolo), 29/04/2013,

URL:< http://www.studistorici.com/2013/04/29/odriscoll_numero_13/ >

Diacronie Studi di Storia Contemporanea $\vartheta$ www.diacronie.it

Risorsa digitale indipendente a carattere storiografico. Uscita trimestrale.

redazione.diacronie@hotmail.it

Comitato di redazione: Marco Abram - Jacopo Bassi - Luca Bufarale - Alessandro Cattunar - Elisa Grandi - Deborah Paci - Fausto Pietrancosta - Matteo Tomasoni - Luca Zuccolo 